\title{
FORMATION AND MISSION (MATT. 28:16-20): CATALYSTS FOR EVANGELIZATION
}

\section{Ezeogamba, Anthony Ikechukwu}

Chukwuemeka Odumegwu Ojukwu University Anambra State, Nigeria

\begin{abstract}
Jesus came from God the Father with the message of salvation. In order to make this massage reach to the ends of the earth for the evangelization of all, both the Jews and Gentiles, he selected twelve apostles out of the disciples that followed him. These twelve he molded and made the "light" of the world and "salt" of the earth and urged them to let their light shine so that people will see their light and glorify their father who is in heaven (Matt. 5:13-16). It is this twelve that followed him from the inception of his ministry to the end of his ministry. The implication is that they were with him from his baptism to his ascension. Having formed the Twelve, he sent them on a mission to evangelize the whole world. The aim of this article is to restate anew the inseparability of formation and mission in the work of evangelization and their indispensability in the work of evangelization. This paper argues that if the mandate of Jesus in Matt. 28:16-20 is duly understood and imbibed then formation, and re-formation of evangelizers cannot be over emphasized. Significantly, the outcome of this research will be of immense benefit to all evangelizers and missionaries all over the world.
\end{abstract}

KEY WORDS: formation, mission, evangelization

\section{INTRODUCTION}

Jesus came from the Father to the world, the only one who had seen the father, it was through him that all things were made (John 1:1ff). The Church is the after effect of Christ's mission on earth. Church is a kind of kahal Yahweh (assembly of God) of Old Testament. While kahal Yahweh is of Old Testament, Church is of New Testament. The Church is an assembly that gathers in the name of Christ. According to St. Paul "when the fullness of time was come God sent His Son, born of a woman, born under the law, that He might redeem them who were under the law, that we might receive the adoption of sons" (Gal. 4:4-6). This shows that Christ's taking the form of man is to show humanity the way to heaven.

Jesus left the seclusion of Nazareth at the age of thirty and began his public ministry as a teacher in Israel so as to lead the strayed humanity back to God (Gen 3:23-24). To make his work very effective and to last forever till the end of time (Matt 28:20), out of his numerous disciples he selected the Twelve and named them apostles. During the period of formation of his followers and missionary activities, in their presence, he was really "mighty in words and works". Thus, he confirmed his teaching with many signs and wonders. These imply that out of his disciples he

Print ISSN: 2052-6350(Print), Online ISSN: 2052-6369(Online) 

chose twelve men, whom he carefully prepared to be his Apostles, they would be bearers of his message to the whole mankind. They witnessed his miracles and his resurrection. He invested them with the powers, which he himself had received, and appointed Simon Peter to be their head and leader. No wonder he told them: "I call you friends, because I have made known to you everything I have learnt from my Father. You did not choose me, no I chose you; and I commissioned you to go out and to bear fruit, fruit that will last . . ." (John 15:15b-16a). This structure of forming and sending on mission seem to be portrayed clearly in the first five books of the New Testament namely the four gospels and the Acts of the Apostles. The gospels (Matthew, Mark, Luke and John) portray the selection and training of apostles whereas Acts of the apostles expresses the missionary enterprise of the apostles and their converts. Graphically, the expositions of these five books show Jesus handing over the baton of the relay team to the apostles and the apostles handing it over to their converts and the process has been endless even till today. In this case, Jesus handed over to his apostles (Matt. 28:16-20) and the apostles through those they handed over reached us. It is our turn therefore, to always acquaint ourselves from time to time what Jesus and his followers did so that we can do even greater works.

The work Jesus did physically here on earth ended with his ascension into heaven. Ascension is the traditional name given to the transit of the risen glory of God after the resurrection. ${ }^{1}$ The following passages: Mark 16:19-20; Luke 24:44-53, Acts 1:1-14; 1 Pet.3:22; 1 Tim. 3:16; Heb. 4:14 reveal that ascension symbolizes the final departure of the physical Jesus after his appearances to the gathered disciples and some persons as well as the theological import of that movement. Simply put, ascension is a sign that Christ's earthly mission had been fulfilled. The implication is that the present day ministers should learn from Christ what it means to form someone before sending him or her on mission as he himself laid down examples for his followers (Mark 6:7-13). Jesus' one methodology was to prepare and send and never send and prepare. Let us at this juncture consider some important definitions that will aid in the understanding of this passage.

Formation: Formation is related in one way or the other with the following terms: development, creation, and shaping of something. As a development, it could be seen in a process by which something develops or take a particular mould. For instance, formation can lead to the influencing of one's character or way of looking at reality. The disciples of Jesus through his actions and words were emboldened to change the whole world. Only God knows how the timid Peter and fellow apostles suddenly turned into courageous men that touched the heart of Jews to the extent of asking, "brethren, what shall we do? (Acts 1:15-26; 2:14-41 especially verse 37). Those are fruits of formation spurred by the gift of the Holy Spirit. So formation in form of creation is the process of bringing something into existence which has not been there. ${ }^{2}$ The disciples and especially the twelve were once ordinary men but Jesus through his actions and words produced in them

\footnotetext{
${ }^{1}$ M. Dennis Hamm in The Collegeville Pastoral Dictionary of Biblical Theology p.49 Liturgical Press.

2 Microsoft Encarta, 2009.
}

Print ISSN: 2052-6350(Print), Online ISSN: 2052-6369(Online) 

extraordinary men of God that changed the shape of the universe after Christ's example. The next word that needs explanation for the proper understanding of this topic under consideration is mission.

Mission and the Church: Mission and missionary work are the life or oxygen of the Church otherwise the Church would have become vestigial. The word mission has varied meaning as used by the Church, all of which stem from the apostolic instruction given to the Apostles by Christ himself (Mark 6:7-13) which involves the work of the Church as the great evangelizer and motivator. Let us just take an aspect of these varied usages which is adequate for this work. A mission from the point of view of area or territory to be evangelized is defined as "A territory administered by a priest appointed by the congregation of Propagation of the Faith. Some of these territories have been assigned to the administration of religious orders who appoint superiors over them. As soon as such a district develops, it is made into a prefecture apostolic." 3 This is what is formally understood to be the mission area as understood by the Church. In terms of Church workers, mission is "a body of people sent by a church to another part of the country or to a foreign country to spread their faith or do medical or social work." 4 It is a campaign of religious workers. Precisely as it affects the day to day evangelization of people by individuals, "The concept of mission for the individual is complementary to that of giving witness to Christ and His teaching (Acts $2: 24-32 ; 3: 15 ; 4: 10$ ). The Christian bearing the message of salvation is given special aids so that the mission may be accomplished (1 Pet. 2:9; Rom. 15:6-7; Gal. 4:14). Thus, Christians have the understanding that theirs is a participation in the work of the Church in being sent and that this is expressed through: proclaiming the good news, service". ${ }^{5}$ Mission therefore, is the act of a Christian participating in the evangelistic work given to the Church by Christ himself. One who carries the work of evangelization on behalf of the Church is called a missionary. The Church, therefore, in obedience to God through Christ is missionary in nature. Hence, Ad Gentes Divinitus opines,

The Church, in obedience to the command of her founder (Mark 16:15) and because it is demanded by her own essential universality, strives to preach the Gospel to all men. The apostles, on whom the Church was founded, following the footsteps of Christ preached the word of truth and begot Churches. It is the duty of their successors to carry on this so that the word of God may run and be glorified (2 Thess. 3:1), and the kingdom of God proclaimed and renewed throughout the whole world. ${ }^{6}$

\footnotetext{
${ }^{3}$ Robert C. Broderick, (ed) A to Z Guide to the Catholic Faith (Nashville: Thomas Nelson pub., 2005) p.437

${ }^{4}$ Microsoft Encarta, 2009.

${ }^{5}$ Broderick, (ed) p. 437

${ }^{6}$ Augustine Flannery, (Gen.Ed) Decree on the Church's Missionary Activities (Ad Gentes Divinitus) no. 26 in Vatican II (New Delhi: St. Pauls, 2007) 715
}

Print ISSN: 2052-6350(Print), Online ISSN: 2052-6369(Online) 
Published by European Centre for Research Training and Development UK (www.eajournals.org)

Anyone who undertakes a missionary work does that on behalf of the Church and not on the person's behalf. But no one would be sent to represent the Church for missionary work without a message, hence proper training. The implication is that anyone who will be sent on a mission must receive proper training and thus imbued with the message. This is because no one can teach without the requisite knowledge and backing (Matt. 28:20). To substantiate the above claims, Vatican II teaches:

Those who are sent to the different nations should, as worthy ministers of Christ, be nourished by the "words of faith and with good doctrine" (1 Tim. 4:6) which they will draw mainly from sacred Scripture while they are studying the mystery of Christ, whose preachers and witnesses they will be. So all missionaries - priests, brothers, sisters and lay people- should be trained and formed, each according to their state, lest they be found unequal to the demands of their future task. From the very beginning their doctrinal training should be such that they understand both the universality of the Church and the diversity of peoples. this holds for all the studies which they might usefully be instructed so that they might have a general knowledge of peoples, cultures and religions, not only with regard to the past but also with respect to the present time. Whoever is to go among another people must hold their inheritance, language and way of life in great esteem. ${ }^{7}$

Improper understanding of the mind of the Church as stated above may lead the evangelized to turn round and blame the missionaries that brought the message of the Gospel to them. A good example will be the type of blame a great Igbo historian, R. A. Ozigbo rained on the early missionaries of eastern Nigeria especially, Shanahan of Eastern Nigeria thus,

"One of the devastating proofs of Bishop Shanahan's lack of apostolic imagination was his myopia as regards the needs and place of the local clergy in his prefecture of the lower Niger. He certainly had soldierly energy and drive but he lacked mental vision and ministerial imagination .... With the repeated urgings of heads of mission jurisdictions by Propaganda Fide, to send promising students to Rome at Rome's expense Shanahan could have sent John Anyogu to Rome."8

Though this fact was refuted by some theologians like Mbefo, Luke ${ }^{9}$ but it has to be avoided from the beginning so that no one would have any opportunity to criticize the missionaries. Hence, the Fathers of the Church further submits, "It is very necessary for the future missionary that he undertakes missiological studies, that he knows, that is, the teaching and the laws of the Church regarding missionary activity, that he be aware of the paths which have been followed by the

\footnotetext{
${ }^{7}$ Augustine Flannery, (Gen.Ed), pp740-741.

${ }^{8}$ Ozigbo, R. A. "Catholic Seminaries in Eastern Nigeria 1924-1996: and historical Excursion" in The Nigerian Journal of Theology. June 1998, vol. 12), p 32

9 "In Defence of the Missionaries in Eastern Nigeria" in The Nigerian Journal of Theology (Owerri: Catholic Theological Association of Nigeria, June 1999, vol. 13) pp 46-62
}

Print ISSN: 2052-6350(Print), Online ISSN: 2052-6369(Online) 
Published by European Centre for Research Training and Development UK (www.eajournals.org) messengers of the Gospel down through the centuries, and that he be familiar with the present state of the missions and with the methods considered most effective in the present time." ${ }^{10} \mathrm{In}$ order to authenticate the importance of formation, Ezeogamba Anthony wrote:

What is addressed in Acts 18:24-28 is how Priscilla and Aquila who were well versed in Christian theology saw Apollos, who though vibrant in his rhetorical ability to communicate theology but with inadequate theology, and took him home for proper and full instruction on Christian theology. The two have the knowledge but they may not be as vibrant and as skilful as Apollos in communicating it. When they saw Apollos' talent they decided to make him whole so that he can go about making others whole ... It is not that Apollos had no knowledge at all, he had something but not a complete knowledge of the way of God. He has the interest and the skill but he has not adequate knowledge. The interesting thing is that when confronted he humbly followed suit; the fruit of that was unquantifiable. $^{11}$

After his proper training Apollos vigorously went about preaching and winning souls more than ever. Thus, "The proper instruction Apollos received helped him to have a lot of impact on the Christians at Ephesus and some Corinthians as well as those from Achaia. In Corinth Paul presented him as his co-worker as well as the one who waters all that he had planted in Corinth or the one who builds on the foundation he had already laid down (1 Cor. 3:6-10)."12 Importance of proper formation for those who would be sent on mission on behalf of the Church can never be overemphasized. Proper training or formation is thus a sine qua non for missionary work to be properly done. Proper training or formation of missionaries will help the Church today to appreciate the divine mandate in the letter to the Hebrews, "Remember your leaders, who preached the word of God to you and as you reflect on the outcome of their lives, take their faith as your model" (Heb. 13:7). On this Mbefor says, "If we see farther away than our ancestors, it cannot be attributed to our towering height. Rather it is because we ride on the shoulders of giants who carry us on." 13 Igbo adage says, "Nwata na aju ndi okenye ajuju anaghi agahie uzo," (he who consults elders is like one who has consulted ancestors and will never make any mistake). Hence, for the effectiveness of the mission, the would be missionaries need proper training or formation and missionaries need to be retrained constantly.

\footnotetext{
${ }^{10}$ Flannery, (Gen.Ed) 741.

${ }^{11}$ Ezeogamba, Anthony The Methodology of Priscilla and Aquila (Acts 18:24-28): Challenge for Agents of Human Development in Nigeria in the Theological Education for Human Development and Nation-Building in Africa (Port Harcourt: CIWA Pub., 2010) pp 144-145

12 Ezeogamba, p148.

${ }^{13}$ Luke Mbefo, "In Defence of the Missionaries in Eastern Nigeria" in The Nigerian Journal of Theology (Owerri: Catholic Theological Association of Nigeria, June 1999, vol. 13) 46.
}

Print ISSN: 2052-6350(Print), Online ISSN: 2052-6369(Online) 
Church and Evangelization: The noun evangelization is the art of converting someone or people of an area to Christianity, especially through preaching or missionary work. ${ }^{14}$ Evangelization therefore, has a lot to do with missionary work. Without having in mind to convert, there would never be any need of missionary work. Evangelization to mission work is like left hand and right hand to one another, they are complementary to each other. Evangelization originally meant preaching the gospel to those who had never heard of Jesus or his teachings. But following Vatican II the term has come to mean, more broadly and rightly, "The whole mission of the Church and the activities of the apostolate through which she announces, implants, and brings to maturity the kingdom of God." ${ }^{15}$ Whoever that goes for mission has no other business if not to evangelize the people and plant the seed of faith in that environment. The two terminologies can be inter changed without any contradiction depending on the context. Hence, the primary aim of any missionary is to evangelize the people or area he has been sent. Any person who is part of an evangelization team must necessarily be trained or formed for their work to be properly appreciated and effective too.

\section{Exegesis of Matt. 28:16-20.}

\section{Remote and Immediate Context of Matt. 28:16-20}

In context, the event of Matt. 28:16-20 is remotely followed by the arrest, trial and condemnation of Jesus before Pilate. All the chief priests and the elders of the people met in council so as to bring about the death of Jesus. So they had him bound and brought him before Pilate, the governor, to judge and condemn him. This was successfully executed (Matt. 27:1-2, 11-31). The immediate context of Matt.:28:16-20 is the crucifixion, death, burial and resurrection of Jesus (Matt. 27:3228:10). The resurrection of Jesus marked another stage in his existence and that of the apostles. He appeared to his followers and last of all to the eleven apostles, encouraged them not to lament but to rejoice for he has conquered the world. Before the crucifixion, he was with a physical body that could not pass through walls and closed doors but after the resurrection he appeared with a glorified body that could do everything humans do and even more, like passing through closed doors and windows. It is under the glorified body (exalted and resurrected body) that he met with the eleven in Matt. 28:16-20.

\section{Analysis of Matt. 28:16-20}

David R. Bauer rightly calls Matt. 28:16-20 as a climax with inclusion. ${ }^{16}$ Verse 20 of chapter 28 where Jesus says, "egō meth humōn eimi pasas tas hēmeras eōs tēs sunteleias tou aiōnos" (I will be with you all days until the completion of the age) and verse 23 of chapter 1 where we are provided with prophetic utterance concerning Jesus as regards the name he would be called. "kai kalesousin to onoma autou Emmanouēl ho estin methermēneuomenon meth hēmōn ho theos"(and

\footnotetext{
14 Microsoft Encarta, 2009.

15 Broderick, (ed) p. 228.

${ }^{16}$ David R. Bauer, The Structure of Matthew's Gospel, A Study in Literary Design (Syracuse: Almond Press, 1989) 109
}

Print ISSN: 2052-6350(Print), Online ISSN: 2052-6369(Online) 
Published by European Centre for Research Training and Development UK (www.eajournals.org) they will call him Emmanuel which is being interpreted as God is with us). This two verses appear to the whole book like a bracket. The two verses give us the inclusio. The implication is that the mission is clear from the beginning. The first was prophesied by the prophet thus speaking the mind of the Lord and Jesus himself made the promise to his apostles and by implication to the entire Church.

Majority of scholars structurally divided Matt. 28:16-20 into three main parts namely, Introduction (vv. 16-17); the great declaration (vv. 18-20a) and the great promise (v 20b). The threefold can be described as revelation, command and promise. ${ }^{17}$ Let us now look at them section by section so as to unlock the meaning existing in the units.

\section{Matt. 28:16-17: The Introduction}

The introduction provides us with the following information: the number of the apostles that were there namely eleven which is twelve minus one (Judas). In our context Judas could be seen as one who failed the formation, hence was not qualified for the mission. The implication is that before the final visitation of Jesus to his apostles in Matt. 28:16, Judas had already gone to his place (where he belongs). Furthermore, before Jesus' subsequent declaration and departure, Judas was no longer with them. The introduction also provides us with the locale of the meeting- Galilee, and precisely, on the mountain where they had previously arranged. Galilee as we know is where Jesus started his earthly ministry (Matt. 4:15-16) and where he now gives the command "go . . . and make disciples of all nations ..." (V.19). Galilee, therefore, stands at the beginning and end of Jesus' earthly ministry. ${ }^{18}$ Mountain is very important in the earthly ministry of Jesus, for instance, transfiguration of Jesus took place on a mountain (Matt. 17:1-8). Furthermore, on a mountain, Jesus rejected the tempter and his evil promises (Matt. 4:8-10). Again, it was on a mountain that Jesus rolled out his great sermon (Matt. 5:1-7:27). In this verse 16, Jesus "having fulfilled the Father's will, he declares on a mountain: All authority . . (Matt. 28:18)."19

This introduction also reveals what the apostles did immediately they saw Jesus namely majority of them prostrated before him or worshipped him and few others hesitated probably as a result of lack of understanding who he actually is. The verb used here is edistasan which is 3rd person plural, first aorist, active indicative, from the verb distazō which means "to doubt". This verb is used only in one other place in the NT where it was used to describe the situation of Peter in the face of whether elements as he was walking on the waters (Matt. 14:31). Interestingly, it is associated here also with 'worship' (Matt 14:33) just as in v.17 where we have "worship and doubt" at the same time. Scholars differ on the meaning of this 'doubt' in this verse or on 'who actually doubted.' Is it some of the disciples or some people that joined them to go and meet Jesus; but we

\footnotetext{
${ }^{17}$ Bauer, 112.

${ }^{18}$ Adrian Leske, "Matthew" in The International Bible Commentary (Bangalore: Theological Pub., 2004$) 1395$.

${ }^{19}$ Stephen Westerholm, "Matthew" in The New Interpreter's Bible, One Volume Commentary (Nashville: Abingdon Press, 2010) 657.
} 
Published by European Centre for Research Training and Development UK (www.eajournals.org) are told that it was only the twelve minus one that were there. Reacting to the debate, R.T. France says, "The last time these eleven disciples had seen Jesus was as they ran away from him in Gethsemane; so what sort of reception could they now expect from the master they had deserted? The conflicting instincts to worship the risen Jesus and to avoid a potentially embarrassing encounter make very human sense in this context." ${ }^{20}$ Without discrediting the position of R.T. France, this paper argues that the 'doubt' of verse 17 has nothing to do with faithlessness but rather with lack of fully accepting that the resurrected Christ is still the Christ they used to know. Put differently, it was very difficult for those who doubted to marry the exalted Christ with the previous earthly Christ they used to know, the one they deserted when he needed them most. Hence, their doubt is hinged on the personality of Christ. No wonder why verse 18 said, Jesus "came to them." Probably he moved closer to them for them to see him well. This paper believes that the doubt of the few of the apostles were cleared through the declaration of verses 18-20. It is necessary that full understanding of Christ will enhance the mission of the eleven, hence the declaration of verses 18-20. Through the declaration, Jesus needed to convince them that he is truly alive and therefore promised to be with them till the end of time (v.20) no matter their unfaithfulness. A little survey reveals that there is a connection between v.17 and Matt. 14:31-33. For in 14:31-33 Jesus cleared the fear/doubt of Peter as well as that of other disciples and those who happened to be around. One can rightly conclude with Bauer by saying that, "The earthly Jesus who taught his disciples in Galilee and travelled with them to Jerusalem is one with the exalted Christ who continues to dwell with his disciples, teaching and guiding them as they seek to fulfil the charge Jesus has given them." ${ }^{21}$ Finally, Jesus was the one who approached the apostles and made the declaration which this paper prefers to call 'missionary mandate.' The locale of this meeting has a very high theological and missionary significance. Bauer says,

The location 'unto Galilee' echoes Matthew's statement in 4:12, where Jesus is said to have withdrawn 'unto Galilee' just before he began his public ministry; Galilee is therefore the sphere of eschatological ministry for both Jesus and the disciples. In Matthew, the mountain is the place of revelation $(5: 1 ; 17: 1-8)$. Moreover, the command of Jesus points back to the instruction Jesus gave his disciples through the women in $28: 10{ }^{22}$

Galilee provided Jesus the privacy he needed at any point in time to spiritually invigorate himself as well as a good environment where he can stay with his disciples/followers for proper and adequate instruction to sink in well. Jesus was worshipped to indicate his messiahship or the relationship he has with God. In Matt 4:10 Jesus defeated Satan by telling him that it is only God that should be worshipped and him alone should be served. That worship therefore revealed that his disciples recognized his divinity. It is good to note also that "to worship" and "to fall down" go

\footnotetext{
${ }^{20}$ R.T. France, The New International Commentary on the New Testament, The Gospel of Matthew (Michigan: Grand Rapids, 2007) 1112.

${ }^{21}$ Bauer, 114

22 Bauer, 109-110.
}

Print ISSN: 2052-6350(Print), Online ISSN: 2052-6369(Online) 
Published by European Centre for Research Training and Development UK (www.eajournals.org)

hand in hand in the New Testament and for one to accept to fall down and worship the other means acknowledgement of the other's divinity or superiority (Matt 4:9; 17:6; 18:26, 29; 26:39).

\section{The Great Missionary Mandate/Declaration (vv18-20)}

These two verses could be broken further down into three smaller units namely the declaration of his authority (v.18); the great commission (vv 19-20a); and the eternal promise (v.20b). The three units are closely united. It is verse $18 \mathrm{~b}$ that provides foundation, root or basis for the commission of the apostles (vv. 19-20a) as well as the eternal promise of being with them (v.20b). One flows from the other namely, authority- commission- promise.

The declaration of his authority (v.18). The phrase that captures the mind all readers in this verse is: pasa edothē moi, meaning "all authority was given to me." "All authority" means without exception. This seems to call to mind the authority given to the Son of Man of Dan. 7:13-14. ${ }^{23}$ Edothē is aorist passive from the verb, didomi meaning "to give." There is a connection between this verse and Matt 11:25-27. In 11:25-27 Jesus emphasized that everything has been handed over to him by his father. "With regards to the proclamation of v.18b, the authority which is given to Jesus (by God) is inclusive in scope, and this inclusiveness is emphasized by repetition: 'all authority', 'in heaven and earth'. This inclusiveness of the authority of Jesus corresponds to the inclusive scope of the missionary charge in vv. 19-20a." ${ }^{24}$ Let us briefly review some statements in the gospel itself that indicate and emphasize the authority of Jesus. Jesus' authority is greater than that of John (Matt. 3:1-17); Jesus is greater than the Temple, Jonah, Solomon (Matt. 12:6, 41, 42). Jesus has power over Satan (Matt 4:1-11). He had the commanding authority over all men hence could summon disciples he made fishers of men instead of them remaining fishermen (Matt. 4:19-21). Jesus taught, preached and healed with authority unlike the Pharisees and chief priests (Matt. 4:23; 9:35; 8-9; 11:1). This authority of Jesus which he was manifesting little by little during his earthly ministry is highly manifested in the interpretation of the Torah and even outright rejection of certain previously accepted demands of the Torah like healing on a Sabbath day in the Sermon on the Mount (Matt 5-7). Jesus as one having the authority of God could also heal from a distance (Matt. 8:9-13). Jesus has the authority to forgive sins (Matt 9:2-8). He has the authority to raise the dead, sight to the blind, lame to walk, lepers to be cleansed, the deaf to hear, the dignity of the poor restored (Matt 9:18-26; 11:5, 23-30). Jesus has even the authority to dispense this authority to whoever he wills (Matt 10; 16:18, 19). What Jesus said in Matt. 11:27 reveals the source of the authority he has and has a lot to do with Matt. 28:18 and by extension vv 19-20. It is good to note that Jesus himself was killed because of the misunderstanding of the authority he has. The Pharisees and Chief Priests condemned Jesus because he was accused of blasphemy, that is, claiming to be equal to God or making himself son of God which is also manifested in his healing the sick on a Sabbath day (Matt. 9:3; 12:14; 26:63-68). In brief, Jesus was condemned because the Jews were afraid of his authority. So before his ascension, he had to re-emphasize to his followers that all authority has been given to him by his father who is in heaven

\footnotetext{
${ }^{23}$ Craig L. Blomberg, "Matthew" in The Commentary on the New Testament Use of the Old Testament (Michigan: Baker Academic, 2007) 100.

${ }^{24}$ Bauer, 110
}

Print ISSN: 2052-6350(Print), Online ISSN: 2052-6369(Online) 
and also reminded them that he is giving them the same authority (Matt. 28:18-20). On this Bauer opines, "The exalted Christ extends the authority the Father has given him to the entire range of the universe: 'in heaven and on earth.'"25

\section{The great commission (vv. 19-20a)}

It is good to note that the commission of verses 19-20a is introduced by the finite verb mathèteusate which is second person plural, first aorist, active imperative from the verb mathēteuō which simply means "to make disciple"26, to make one a follower of Christ. In the NT translation, it means to make a disciple of , to train in discipleship (v.19 and Acts 14:21); to be trained, disciplined, instructed (Matt. 13:52) ${ }^{27}$ The implication is that the apostles were given the mandate of making others disciples by first of all teaching them all that they learnt from him and if they happen to accept the teaching as they were taught, the apostles were also urged to complete the process by making them his followers through baptism. That is why up till today, baptism remains the only road to Christendom. "Jesus' vision of the future heavenly enthronement of the Son of Man in 24:30 led naturally into a mission to gather his chosen people from all over the earth (24:31). The first part of that vision is now achieved (v.18), and so the second part can begin." ${ }^{28}$ The essence of the proclamation is to make them disciples of Jesus.

The fundamental question would be, who is a disciple and who is an apostle? In the context of the life, death, resurrection and ascension of Jesus, a disciple is a follower of Christ. In Antiochean parlance disciples are Christians (Acts 11:26) since Christians are followers of Christ who were discovered to have been behaving like their leader (Jesus). It is out of the disciples that Jesus picked the apostles to stand for the twelve tribes of Israel and as the new leaders of his people. In the passage under consideration, they are eleven because Judas had left them and went to where he belongs (Acts 1:16). It is good to note that every apostle is a disciple but not every disciple is an apostle. Apostles are the leaders of the Church (Acts 15:1-35). The word disciple occurs about 270 times in the NT. Most of these occurrences refer to the disciples of Jesus. In John's Gospel alone, it occurs about 80 times. Among the Jews there were teachers of the Law and these teachers had disciples or students who followed them. To these disciples the rabbis transmitted their doctrines. These disciples strove to preserve the exact teaching of the rabbi word for word to the best of his ability, and the most successful disciple was the one who could best repeat by memory what he had heard (Matt 22:16; Mark 2:18). On the part of Jesus and his disciples, he demanded a more complete personal surrender to himself than the rabbis (Matt. 10:37-42; Luke 14:26-33) in their imitation of him. A disciple, therefore, is a learner who learns from his master so as to take after the Master. He does not take after the master from the point of view of becoming the master but from the point of view of becoming a representative, an ambassador of Christ

\footnotetext{
25 Bauer, 121.

${ }^{26}$ Fritz Rienecker, A Linguistic Key To The Greek New Testament (Michigan: Grand Rapids, 1980$) 87$.

27 Wesley J. Perschbacher, (ed.) The New Analytical Greek Lexicon (Massachusetts: Hendrickson Pub., 2001$) 262$.

${ }^{28}$ France, 1114
}

Print ISSN: 2052-6350(Print), Online ISSN: 2052-6369(Online) 
himself. They were not called by Christ to become masters themselves but to become his followers, and graduate into becoming his representatives and ambassadors in the world. That is why he could tell them that they are the salt and light of the earth and world respectively. ${ }^{29}$ "A disciple is one who is called to follow Jesus, who has encountered God's reign/empire (4:17, 1822)." ${ }^{30}$ So when Jesus talks of making disciples of all ethnē ('nations') he wants them to go with vigour to convert and make the whole world his disciples.

A closer look at the phrase, panta ta ethnē "all the nations" (v.19) reveals that Jesus' command is a movement from ethnocentrism to universalism. In Matt 10: 5-6, Jesus ordered his disciples to go only to the lost sheep of the house of Israel but when one looks at other passages the tone of Matthew's gospel from genealogy (Matt.1) to 28:20b reveal that Matthew's gospel is universalistic in nature. Let's just mention few incidences: Firstly, the encounter between Jesus and the Canaanite woman (Matt 15:22-28). Secondly, Jesus promised the called disciples that he will make them fishers of people ( Matt 4:19). Thirdly, Jesus emphatically called his disciples 'Salt of the earth, and light of the world' (Matt. 5:13,14). Fourthly, a survey of the mighty works of Jesus in Matt 89 reveal more this idea of universalism in the Gospel of Matthew. Fifthly, before the world comes to an end, the 'Good News' will be preached to all people (Matt 24: 14; 25:31-46; 26:13). And finally, this universalism comes to its fullness in Matt. 28:16-20. ${ }^{31}$

Mathēteuō is preceded by a participle: poreuthentes which is first aorist, passive participle, nominative plural, masculine noun from the word poreuomai meaning "to go", from one place to another (Matt. 17:27; 18:12); "to go away", "depart" (Matt. 24:1; 25:41). ${ }^{32}$ In our context, it means "to go" and accomplish the wish of the one who was sending them. This participle is used both here and in chapter 10 in order to emphasize the contrast between the exclusive mission of chapter 10 and the inclusive mission here. The implication here is that it is not just the mission of the eleven or gathered disciples but their converts too. They have that same mandate of making others 'Christians.' Poreuomai is also a circumstantial participle, expressing the circumstance which surrounds or attends the activity of making others disciples. ${ }^{33}$ Poreuomai and mathēteuō give meaning to one another. They are imperative in meaning. Jesus did not just other them "to go" without a mission. The mission he gave to them was to convert people through the transfer of the trainings they have received to others so as to make them Christians. How to make them disciples is what follows below.

\footnotetext{
${ }^{29}$ Anthony Ezeogamba, "Serviceability and Conviviality (John 13:1-17): Indispensable Virtues in the Life of A Christian" in The Journal of the Literati Philosophia, Vol. 2, No. 2 (Enugu: SNAAP Press, 2015) 23

${ }^{30}$ Warren Carter, Matthew and the Margins, A Sociopolitical and Religious Reading (India: Theological Pub., 2007) 552.

${ }^{31}$ Bauer, 124.

32 Perschbacher, 339.

${ }^{33}$ Bauer, 111
}

Print ISSN: 2052-6350(Print), Online ISSN: 2052-6369(Online) 
Published by European Centre for Research Training and Development UK (www.eajournals.org)

There are two other participles that are associated with the order, "to go" and they are baptizontes ("baptizing") which is present participle, active mood, nominative case, masculine plural from the word baptizō meaning "to baptize", to dip, immerse; to cleanse or purify by washing; to administer the rite of baptism, it has a lot to do with Christian baptism as an act of dedication (Acts 22:16). ${ }^{34}$ This has only been mentioned previously in regards to John's baptism Matt. 3:1-17; 21:25), now it has become the symbol of purification and renewal, a regeneration as a child of God which all must adopt. It means entering a renewed type of relationship with God. ${ }^{35}$ Hence, baptizō (baptism) in our context means to purify one of impurities (sins) that block and destroy one's sonship or daughtership in the fatherhood of God. Baptizō is the act of becoming an adopted child of God by being a true follower of Jesus Christ the only true Son of the Father. It is the only thing that makes one to be a member of Christ's body which is the Church where Christ is the head of that body. "Christian life is that specific life of the Trinity which began when we were baptised in the name of the Father, and of the Son and of the Holy Spirit. We became regenerated and incorporated into Christ, to live God's life." ${ }^{36}$ One thing is very clear here also, baptism is very important for salvation.

Another important participle is didaskontes ("teaching") which is present participle, active mood, nominative case, masculine plural and from the Greek word didaskalos which means "to teach" or to speak in a public assembly (1 Tim. 2:12); to direct, admonish (Matt. 28:15; Rom 2:21). ${ }^{37}$ This section is particularly spectacular because there are two things that are special about it. In Matt 16:20 after Peter's confession, the disciples were commanded not to reveal Christ identity to anyone; again after the event of transfiguration in Matt. 17:9 as Jesus and his disciples were descending from the mountain, Christ charged them not to reveal what happened at the transfiguration to anybody until after his resurrection but in Matt. 28:19-20, which is after the resurrection, he commanded his disciples to teach all nations by implication he charged them to make him known in the whole world. Thus, ordering them to teach people all that he had taught them and all that they had kept in their minds all the periods of his earthly ministry.

Furthermore, in Matt. 10 the mandate is to go and do only two things namely to preach to people about what is good and what is bad and to heal or restore people to good health both spiritually and physically, whereas in verse 20 they were given additional function which is didaskalos "to teach." This order 'to go and teach' came when Jesus seems no longer teaching his apostles but for them to go and teach others all that he had earlier taught them and which they must have learnt

\footnotetext{
${ }^{34}$ Perschbacher, 66.

35 Leske, 1395

${ }^{36}$ Fides, Monthly Bulletin May 2018: The Proper of Daily Masses and Readings in English and Igbo (Awka: Fides Communications, 2018) 61

${ }^{37}$ Perschbacher, 98.
}

Print ISSN: 2052-6350(Print), Online ISSN: 2052-6369(Online) 

from him especially on the proper interpretation and value of Torah as contained in Matt 5-7 and other areas in the Matthean gospel.

\section{The Eternal Promise of Never To Abandon Them (v.20b).}

The promise of Jesus, egō meth humōn eimi "I will be with you" is a promise that emerged at the beginning of the Gospel (Matt. 1:23) and reached its climax in Matt 28:20b thus forming an inclusio. Within the gospel itself, there are other instances of Jesus showing signs that he will always be with his disciples. For instance, in Matt.18:20 Jesus declared, "For where two or three are gathered in my name, I am there among them." Jesus promises to be with his disciples in his glory after his earthly sojourn, He wanted them to be awake with him in the Gethsemane (Matt. 26:29, 38,40). All these pockets of "be with you" reached its summit in Matt. 28:20b. Jesus knew that going out to teach will never be easy but the disciples do not know this and that is why there are words of encouragement (Matt. 10:22; 24:13). That is why he could tell them, "Look, I am sending you out like sheep among wolves; so be cunning as snakes and yet innocent as doves" (Matt. 10:16). Such will enable them to succeed. The above statement is backed up with a firm promise to be with them. Is like in Matt. 28:20b he told them, 'though I am sending you out like sheep among wolves' but behold, "I am with always; yes, to the end of time." On this a scholar says, "The commands of Matt. 28:19-20a are followed by the declaration of v.20b, which promises the presence of Christ with the disciples as they carry out the mission of vv. 19-20a and thus substantiates the command. The disciples are encouraged to fulfil the instructions of vv19-20a because of the knowledge that Jesus continues to be with them." ${ }^{38}$

\section{EVALUATION AND CONCLUSION}

A missionary must be taught so as to teach others. Hence, Jesus called the twelve and instructed them on how to extend him in the world, therefore, they were given the power to preach, teach, and to baptize. They were even encouraged to go ahead fearlessly through the knowledge that he will always be with them. Jesus during the training of the apostles, he used to send them out on missionary works from time to time (Matt. 10) until the time he was leaving the world. This methodology of Christ reminds us of the importance of formation, retraining and mission. Jesus tested them severally before he handed over to them the entire mission. This is highly encouraged for various leaders of the Church in their various levels of administration. The Catholic Diocese of Awka does not joke with this idea of "Ongoing formation" for her priests. Awka diocese has training for the newly ordained, for the newly appointed parish priests. It organizes from time to time theological seminars, liturgical seminars, annual retreats, etc.

This paper recommends the following to the leaders of the church, firstly, to have as a guiding principle the saying: "No formation no missionary work." Secondly, the one that is formed, should be retrained from time to time, hence the saying, "Publish or perish." Thirdly annual appraisal of all personnel should be conducted. This will spur them into so many missionary initiatives and endeavours. Conclusively, this paper argues that if the mandate of Jesus in Matt. 28:16-20 is duly

${ }^{38}$ Bauer, 111

Print ISSN: 2052-6350(Print), Online ISSN: 2052-6369(Online) 
Global Journal of Arts, Humanities and Social Sciences

Vol.7, No. 5, pp.25-38, May 2019

Published by European Centre for Research Training and Development UK (www.eajournals.org)

understood and imbibed as explained above then formation, and re-formation of evangelizers cannot be over emphasized. There is no doubt that this paper will be of immense significance to all evangelizers and missionaries all over the world. 